Available at http://jurnal.stie-aas.ac.id/index.php/jie

Jurnal Ilmiah Ekonomi Islam, 5(03), 2019, 265-276

\title{
Strategy Analysis of Building Sharia Residential Property Business without Banks (A Case Study of "Semarang Ngaliyan Residence" Syariah Housing in West Semarang)
}

\author{
1* Millatun Nadzifah, ${ }^{2}$ Zuhdan Ady Fataron \\ ${ }^{1,2}$ Fakultas Ekonomi dan Bisnis Islam, UIN Walisongo, Indonesia \\ *Email korenpondensi: nadzifahmillatun@gmail.com
}

\begin{abstract}
This article is aimed to analyze how the structure of building a sharia home property business without banks. The most recent alternative housing is housing with the concept of sharia without using national banking mortgages. This study used qualitative methods by examining some credible sources in obtaining the data. The results showed that based on the analysis of the residential property business Ngaliyan Residence has been able to answer 9 points of reference BMC analysis (Business Model Canvas) which includes; Value Propositions, Customer Segments, Channels, Customer Relationships, Key Resources, Key Activities, Key Partnerships, andCost Structure. Service strategy is one of the strategies implemented in Ngaliyan Residence for a market segment applied by Ngaliyan Residence, which in turn can realize customer loyalty.
\end{abstract}

Keywords: Strategy, Sharia Housing, without Bank

Saran sitasi: Nadzifah, M., \& Fataron, Z. A. (2019). Strategy Analysis of Building Sharia Residential Property Business without Banks (A Case Study of "Semarang Ngaliyan Residence" Syariah Housing in West Semarang). Jurnal Ilmiah Ekonomi Islam, 5(03), 265-276. doi: http://dx.doi.org/10.29040/jiei.v5i3.645

DOI: http://dx.doi.org/10.29040/jiei.v5i3.645

\section{Introduction}

House is still being the top choice to settle down compared to apartments etc. In general, it is a basic necessity for each individual. Regardless of its function to settle, a place to shelter from rain, pollution, sun, and so on. It also functions as a safe and comfortable place for family gathering. It is also the most desirable asset for each individual in each generation. So to get qualified house, we need a strategic location, safety, comfortable environment and have clean enough air from various impacts of air pollution caused by motorized vehicles or factory waste. In addition, a civilization around the house also has significant role in building character of a family especially children who are still in the stage of forming their identity.

The need of having a house in Indonesian society significantly increases every year. Based on the results of the 2018 Indonesian Housing Financing Outlook discussion, the Director General of Housing Financing at the Ministry of Public Works and Public Housing (PUPR) said that every year it takes around 800 thousand to 1 million new housing units, whereas until the end of 2018, the number of Indonesian people who had not owning houses reached 13.5 million, and in 2025 according to the Director General of 
Housing Finance Ministry of PUPR Maurin Sitorus, the cumulative need of housing reached 30 million units, so that many people find it difficult to meet the need of housing a place to live with family or to make an investment, with a population growth rate of $0.37 \%$ per year and a population density of 987 people $/ \mathrm{km}^{2}$ (BPS, 2010) . and also Because of the limited number of land and its unstoppable rising prices as the result of a continuous increase of inflation, many people decided not to delay owning home assets from an early age.

Aside from being the largest Muslim country in the world, Indonesian Muslim population at census in 2010 reaches a percentage of more than $87.18 \%$. Adherents of Christianity are $6.96 \%$, Catholics $2.91 \%$ while Hindus are $1.69 \%, 0.72 \%$ are Buddhist, Kong $\mathrm{Hu} \mathrm{Chu} 0.05 \%$ and $0.49 \%$ practice different beliefs (BPS, 2010). As the population increases and the majority of Indonesians are Muslim, the growth of sharia business has shown a rapid increase. The concept of sharia-based economy also penetrated into the property business, especially in residential property. Simply, studying ethics in Islamic business means learning about what is good or bad, right or wrong in the business matter based on the principles of Islamic morality (Faisal, Badroen, 2006). In recent years, the sharia property business in Indonesia has experienced significant growth. According to data, the share of property purchases through the sharia system increased $11.23 \%$ per year with the Property Price Index increasing $4 \%$ in the $3 r d$ quarter and the value of the Property Supply Index rising from the previous quarter by $13 \%$ in the $3 \mathrm{rd}$ quarter of 2018. It can be viewed as a sign of business opportunities for sharia properties still wide open.

At present there are two (2) alternatives for the society to fulfill the needs of their family's residence, namely housing alternatives using KPR banking and alternative housing of sharia without using national banking as the most recently concept housing. The two of these alternatives are purposed to meet the needs of the community in having a home stay with various payment modes and concepts which are offered by each party.

To our best knowledge, the non-bank Islamic mortgage has not been studied extensively as the Islamic mortgage bank has. The research in the later field is prevalent in some countries such as Indonesia (Wulandari, Putri, Kassim, \& Sulung, 2016), Malaysia (Amin, Abdul-Rahman, \& Abdul-Razak, 2013), Nigeria (Usman and Lizam, 2016) and Pakistan (Hamid \& Masood, 2011), so researchers are interested in analyzing strategies for developing a bankless housing business.

Sharia housing is an Islamic, comfortable, safe and civilized concept of residential options without using bank. However, it uses sharia instruments that guarantee no usury, fines and with a sharia-compliant agreement. Sharia housing without bank exists as an answer to the dissatisfaction of the community towards Islamic bank mortgages, where some people assumed that the concept of sharia is only an additional word without implementing the full sharia system. In addition, mortgages in Islamic banking are operated in the banking financial institutions which of purpose is clearly to seek profit. People think twice when dealing with banking.

The concept of sharia housing is expected to meet the desires of people, especially critical urban middle-class people who want to adopt an Islamic lifestyle completely, they turn not to take advantage of conventional and sharia National Banking mortgages, but instead choose alternative sharia-based mortgages on sharia housing from developers. One thing that becomes a challenge in developing sharia property business is capital. Many developers ultimately chose to make loans to banks as initial capital to start this business. But, involving bank in the sharia property business is forbidden because it is based on the fatwa DSN-MUI NO.01 / DSN-MUI // 2004 concerning that bank interest is usury. 
The prohibition of usury is also contained in QS Albaqarah: 279 meaning:

"So if you do not practice (leaving the rest of usury), then know that Allah and His Messenger will fight you. And if you repent (from usury taking), then for you the principal of your treasure; you don't persecute and are not persecuted".

Having capital without involving banks needs different business strategies to be built in the property business, ranging from financing strategies to marketing. Problems in financing may occur because of avoiding the interest of banks. Consequently, financing without banks requires developers to have their own strategies in the matter of financing and marketing to build sharia housing as well as strategies in developing the Sharia Housing property business with a concrete sharia concept.

\section{Literature Review \\ Business}

The word business in Indonesian is derived from the word "business" from English language which means busyness (Arifin, 2009) Etymologically, business has several meanings namely business, commerce, shops, companies, tasks, affairs, rights, commercial business in commerce concern; corporate world; and trading business (KBBI, 2005: 157). Whereas, terminologically, business is an individual activity to produce (profit) or sell goods and services in order to meet the needs of the community (Muhammad Fauroni, 2002).

\section{The Purpose of Islamic Business}

Business development in Islam must be oriented to sharia rule since it functions to control the maintenance of the business practice in following the Islamic rules. With sharia control, business activities are expected to achieve 4 (four) main things as follows: (Prof. Dr. H. Muhammad Djakfar, S.H., 2012)

1. Targets: Material Profit and Non-material Benefits

The purpose of businessesman not only seek the highest form of gain material (qimah madiyah), but must also be able to obtain and provide advantages or benefits immaterial to internal and external (environmental) organization of businesses , such as realizing an atmosphere of brotherhood, social attitude, and so on. The profit discussed doesn't only mean material profit but non-material as well. Islam views that the purpose of a deed is not only oriented towards the qimah of the Ahmadiyya because there are still other orientations, namely the qimah insaniyyah, qimah khuluqiyyah, and qimah ruhiyyah. Qimah insaniyyah means that a businessman can provide humanitarian benefits through employment opportunities, social assistance (alms), and other assistance. Qimah khuluqiyyah means that the values of akhlaq al-karimah (noble character) becomes one that must exist in any activity in the business management so as it influences people build a brotherhood, not only functional or professional relationship. Meanwhile, qimah ruhiyyah means that the action is intended to know Allah's blessings well.

2. Growth means Continously Increase

If the material and non-material benefits have been achieved upon the target, the business person will agitate for growth or increase of each profit as well as will strive for business results in order to get an increasing number every year. These growth efforts must be carried out within the Sharia rules

3. Continuity

Management orientation of a business can't be claimed perfect if only to target the final result and growth. Therefore, business people need to strive continuously so that the achievement of target results can be maintained for a long period.

4. God's blessing or pleasure

The blessing factor to reach the pleasure of Allah is the main goal of the happiness of Muslim's life. When this is reached, this indicates that the terms of two good deeds namely sincerity and accordingly act to sharia are fulfilled. 


\section{Strategies of Building Business}

Strategy is a set of objectives and specific action plan, which if achieved would give the strength of competitiveness. Strategy explains how an organization align capabilities and opportunities existed in market place achieve a goal (Hery, 2002:98). Thus, strategy is a way or plan that is united and connected to the success of the company to face environmental challenges, and designed to ensure the achievement of the main goal of the company through applying the appropriate opportunities by the organization.

(Hery S.E., 2002) also states that strategy is an important and big plan. Strategy explains generally the direction to achieve organizational goals. Increasing value for customers with the aim of creating competitive advantage can be achieved through applying the appropriate strategy. (Mintzberg, 1987) expands and defines the concept of strategy by taking into account the dimension of it. Mintzberg named it "5 $P^{\prime \prime}$ of strategy" namely, (Solihin, 2012).

1. Strategy as a Plan

Strategy as a "plan" is a comprehensive and integrated plan designed to ensure the achievement of the company's main objectives.

2. Strategy as a Ploy

In this case, strategy is a specific maneuver to signal threatening to the company's competitors since the company has better economic strength than competitors.

3. Strategy as a Pattern

Strategy as a pattern shows a series of actions linked to the management of pursuing a goal. In this case, Mintzberg divides strategy as a pattern into 5 categories namely intended strategy (strategy planned by the company through planning process), deliberate strategy (an intentional strategy), unrealized strategy, and realized strategy.

4. Strategy as a Position

Strategy is useful to know the position of the company in the corporate environment.
According to (Cordell, Thompson, Cordell, \& Thompson, 2019), there are 4 strategies which can show the company's position, namely:

a) Market Intensification, this strategy is implemented if the company decides to increase the volume of sales to the market served by the recent company.

b) Market Development, this strategy is implemented if the company decides to increase sales volume to a new target market .

c) Product Development, this strategy is chosen if the company decides to increase sales volume through selling new products to the market currently served by the company.

d) Diversification, this strategy is chosen if the company decides to increase volume of sales through selling new products to new markets.

5. Strategy as a Perspective

In this case the strategy shows the perspectives of the strategists. Strategy is a lively thought in strategist mind and is like an ideology or culture in an organization.

In general, an organization will use one of two types of strategies in a market competition as follows: the first strategy is providing products at a lower cost ( cost leadership ), this strategy has a goal to increase value for customers by lowering the cost of the product through repairing or increasing the efficiency in the production process and the decreasing of selling prices. The second strategy is providing a unique product through product differentiation which aims to increase value for the customer by offering products that are not supplied by the competitors. This unique product (superior) is often offered or sold at a more expensive price or the same as usual products (Hery S.E., 2002) .

Strategic management plays an important role in improving organizational performance. Through a well-designed strategy, a company can increase its profits, gain market share, create 
competitive advantage, and increase prosperity or returns for investors. Even good strategies will fail if they are not implemented and evaluated appropriately. A good strategy needs to be prepared and formulated. Formulating strategies is carried out like the decision making process. The manager needs to compile and evaluate various strategic alternatives and then choose a strategy that will provide a competitive advantage for the organization.

After the strategy is formulated, the next step is to implement the strategy. The strategy is claimed successful if its implementation is successful as well. Even though the company has planned an effective strategy, the strategy is still being said that it doesn't work if it's not implemented properly. (Hery S.E., 2002)

\section{Sharia Residential Property Business}

Property is a set or asset of land or building along with facilities and infrastructure that illustrates the inseparable element of the land and building. The business of property is a business related to land and buildings that is located on that land.

In the property business there are a number of parties involved, including the government, owners/developers, users/buyers, banks, and property brokers. The government in the property business is the party that issues regulations and codes for the property business. It has a duty to oversee the property business that takes place in its jurisdiction. The developer is the party who owns the property in the form of land and buildings on it. The owner/developer runs the property business by selling property to the buyer community. The user/buyer is the target party. The bank is a party that provides funds for both developer capital to build property and capital credit / home ownership financing (KPR) for prospective buyers who do not have cash to buy a house. Property broker or agent or broker intercede the buyer with the property seller.

Home ownership financing contracts or commonly called sharia mortgages are implemented based on the Qur'an and Hadith and are not based on the interest or usury system. The interest system is forbidden in Islam, because interest is included in usury, and interest creates economic uncertainty. Etymologically, usury means "extra" (al-ziyadah) or "growth and development" (al-nama'). While the definition of usury according to scholars vary, but in general a common thread asserts that "usury is an extra price levied in contract debts and contract purchase or collect additional assets or principal capital wrongly because of postponing. (Firmansyah \& Gunardi, 2018)

(Oktavianingrum, 2016) in her journal states that mortgages are generally provided by banks with the aim to enable people to build a house, renovate, buy or expand land with payments that can be paid by installment with a little interest each month. The high demand of having a house influences many banks, both conventional banks and Islamic banks, make mortgages as a prominent product. However, in Islamic banking, mortgages are based on the contract used. There are several Sharia KPR contracts, namely: (a) KPR iB Sale and Purchase (murabahah scheme), (b) KPR iB rent (ijarah scheme), (c) KPR iB Rent Buy (Ijarah Muntahia Bittamlik-IMBT) while doing transaction or using a contract or lease agreement (ijarah) on real assets consisting of 2 types of contracts or agreements, including the sale and purchase agreement and IMBT contract. The procedure for this contract is that the buyer leases the assets (house, land, etc.) purchased by the bank which then finished with a changing of ownership at the end of the contract period from the bank to the house buyer, and (d) KPR iB Staged Ownership (musyarakah mutanaqisah) is cooperation between several parties (at least two parties) to buy an asset, the amount of profit and loss will be divided according to the portion determined at the beginning of the contract. Musyarakah Mutanaqisah is a contract that is used at the time of cooperation between the bank and the house buyer. Then between the bank and the house buyer divide the abandonment of a house with a 
payment system that is paid in installments in accordance with an agreed proportion. Thus, Musyarakah Mutanaqisah contract can also be referred as a contract with a reduced partnership concept (Yahya, 2016).

Besides the existence of Islamic mortgages in banks, there are new innovations created by property developers, namely the purchase of housing mortgages type that do not use any financial institutions, but instead use Islamic developers. According to KBBI, a developer is a company that carries out activities for the procurement \& processing of land, terrain, buildings as well as facilities and infrastructure that are intended to be sold or leased. While the definition of property according to KBBI is a property in the form of land, terrain, buildings and facilities and infrastructure that are an inseparable part of the land, terrain or building mentioned. Therefore, it can be concluded that the Sharia mortgage developer is a financing housing abandonment in a company that conducts land acquisition and processing activities using sharia principles without involving intermediaries of bank.

(Umar Shihab, 2005) quoted from a number of Expert opinions on Sharia Economic Principles mentioned the opinions of:

First, the Quraish Shihab states that there are four principles of Islamic economics, namely: 1). Monotheism; 2). Balance; 3). Free

willingness; and 4). Responsibility.

Second, Abd. Muin Salim gives a description of the principles of Islamic economics as follows 1). Monotheism; 2). Istimar or Istikhlaf; 3). Ben efit (al-silah) and harmony (aladalah); 4). Justice ( al-qist ); and 5). Prosperous life and tranquility of the world and the hereafter. Third, Ahmad Muhammad Assad, the principles of Islamic economics are 1). All business is legal;2). Buying and selling is allowed and usury is forbidden; 3). Everyone gets results in line with their business and there is no difference in wages between men and women; 4). The leader has the responsibility to make a balanced distribution of wealth in the community if there is inequality and 5). Forbidden persecution in Islam.

The principles of Islamic economics were developed differently by various experts as discussed by Ibrahim Lubis in His Introduction to Islamic Economics. But, previously he explained his personal opinion about the principles of Islamic economics. The opinion of (Lubis, 1994) is firstly, must not exceed the limits that can endanger the physical and spiritual birth of humans, themselves and others. Secondly, not permissible to hoard wealth without benefiting others. Thirdly, giving alms to those who are entitled ( Mustahiq). Fourthly, not owning the property of others legitimately. Fifth, forbidding usury and allowing trade. And sixth, welcoming the product of outside area means that Islam is paying attention to the free market mechanism which is free from fraud.

\section{Research methods}

\subsection{Research Types, Approaches and Models}

This type of research is a field research, the data obtained by the writer is from the field, either data in the form of interviews or written data (documents). Furthermore, the writer exposed the data found in the field and analyzed them to get an accurate conclusion, (Kountur, 2009). The research is aimed at obtaining illustration in-depth view on how to build Residential Property Business Syariah (Sharia Housing Case Study on "Ngaliyan Residence" West Semarang).

This research design is qualitative, in this study the writer does not make calculations, statistics and so forth, but instead uses scientific emphasis or research that produces findings that are not achieved by statistical procedures or by other means of quantitative procedures. If there are illustrations indicating calculations in the form of numbers (quantitative), then it is intended only to sharpen the analysis and strengthen the research argument being conducted by the writer. (Mulyana, 2001) 


\subsection{Data, Data Collection and Analysis Techniques}

There are two sources of the data used in this study namely primary data and secondary data. Primary data is collected from sharia housing practitioners. Meanwhile, the secondary data includes all literature related to financial instruments, Islamic law and positive laws regarding property financing and other literature that provide additional information to this study, for example: brochures, articles, news, and so on.

Data collection techniques used in this study are as follows; First, reviewing documents in the form of records, books, issues, and other data relating to the subject of research, including articles accessed from the internet. Second, the interview was conducted using the Interview Guidance Sheet. The parties that are considered credible or related to the research chosen as respondents include: developers, marketers and buyers of sharia housing.

The analysis technique used in this qualitative research is descriptive analysis. Descriptive means providing a general description of the research data including the essence of the interview about the concepts and strategies of building a sharia residential property business. The data illustration is arranged based on the writer's framework. It will be analyzed critically using BMC analytical tools (Business Model Canvas) to analyze whether the business of residential properties sharia Ngaliyan Residence already organized or need more improvement. So there is continuity improvement in business to further generate conclusions and solutions.

\section{Findings and Discussion}

\subsection{Profile of Ngaliyan Resindence}

Syariah Ngaliyan Residence is the first housing in the city of Semarang. Strategically located on J1. Karonsih Raya Ngaliyan Semarang. 'Ngaliyan Residence' has committed to create a concept of sharia housing properties in Indonesia without the involvement of banks, without usury calculations, and to be protected from problematic contracts. It is hoped that this concept will continue to grow and dominate the market by providing convenient products and facilities because the opportunity to develop Islamic business property is very large and the opportunity of occupying demand for the concept of sharia is also great. Communities, especially Muslims, definitely need sharia-based housing with good quality, affordable prices, good facilities and a comfortable environment.

\subsection{BMC analysis}

Following are the results of BMC analysis on the "Ngaliyan Residence" residential property business gathered from interview results with literature studies based on 9 BMC points. (David, Personal interview, 2019)

1. Value Propositions, keyword: solve

Ngaliyan Residence is the first sharia housing in the city of Semarang established in 2017. Value Propositions offered by houses of sharia developers are not applying usury / interest, fines, confiscation, BI checking processes, and so forth. They are distinguished from other sharia housing, especially those that use the services of banking financial institutions. The excellent points of this concept are not applying usury/interest, fines, confiscation, BI checking process, and etc.

2. Customer segment, keyword: pain.

The research finding of the Ngaliyan Residence regarding customer segment are:

a. New families consisting of 2 children who are under 10 years old, and mostly work as Managers and any job that requires husband to leave his wife such as: sailing, etc.

b. Consumers who have not become regular employees with a working period of less than 2 years, entrepreneurs, and those who are aged over 50 years. And

c. Critical urban middle-class Community and also people who want to apply Islamic lifestyle completely as well as people who began turning to leave either conventional or Islamic mortgage banking. 
3. Channels, keyword: delivery

Buying a house uses istishna contract. Istishna contract was chosen when going to buy a house but had not yet been built or unavailable. This kind of payments can be made in cash or non-cash. If payment is made in cash, the consumer is allowed to pay at the beginning of the contract or when the house is bestowed by the developer. As for the type of non-cash payment, the developer provides the opportunity for consumers to pay partially at the beginning of the contract then the rest is paid when the house is handed over. In addition, for non-cash payment, consumers can also pay by installments with a maximum tenor of 2 years. In addition, some of the developer provides projected payment every month so that the buyers know how much has been paid and how much still have to be paid.

4. Customer Relationships, keywords: Loyalty, Fanatics, Repeatable

This sharia developer also did not include elements of usury / interest in its transaction. In the case of usury / interest, the developer will provide education to prospective customers. Islamic developers or developers do not stipulate the collection of fines when consumers are unable to meet obligations on time, especially in home mortgage payments. With the proven concept applied, the buyer will be convenient and not even reluctant to recommend the product to other potential buyers.

5. Revenue Streams, Keyword: Get Money

The profit received by Ngaliyan Residence is the result of investor cooperation. Ngaliyan residence does not receive any benefits from fines or confiscation.

6. Key Resources, Keywords: HR and Capital Ngaliyan Residence needs Human resources in the fields of marketing, considering sharia business of Ngaliyan residential property is the first residence with sharia concept in Semarang. The capital in building the Ngaliyan Residence business is from personal fund, or by other alternatives namely by inviting investor cooperation. In this sharia residential property business, Ngaliyan Residence works with 2 types of investors, namely landowners and project development investors.

7. Key Activities, Keyword: Operation Procedure

Innovation created by Ngaliyan Residence in developing this business is done by running the principles of Islamic about business development. They must be free from element of which is conversed to al-Qur'an and Sunnah. In addition, it must be free of dharar (danger), jahalah (obscurity), and zhulm (harmful of unfair to one party). Transaction mechanism must be fair, not harmful, and not only benefit one party.

8. Key Partnerships, Keyword: Collaboration and Partnership

Business by sharia residential property developers is a business with high risk and high capital. Then, for gaining the capital, Ngaliyan Residence cooperates with investors. In this sharia residential property business, Ngaliyan Residence works with 2 types of investors, namely landowners and project development investors. In addition, Ngaliyan Residence also cooperates with 'IBU KOTA' fancy store whose address is in Gg. Pinggir No.12, Kranggan, Kec. Central Semarang, Semarang City, Central Java. This cooperation was carried out by Ngaliyan Residence because the concept of payment in sharia housing 'Ngaliyan Residence' is with gold, because the value of gold will always remain stable even more stable than the value of the rupiah. So that every price or margin to be paid will be converted to the value of gold.

9. Cost Structure, Keyword: Spending Money Costs to be reckoned with and decided by the developer consists of a fixed cost and variable costs. The fixed costs in building Ngaliyan Sharia residential property business include the cost of land acquisition, land 
certification costs, house maket costs, and property tax, and others. Variable costs in building this business include; The cost of the field survey, the maintenance of permits, the cost of construction materials, the cost of construction marketing staff, and others .

\subsection{Strategy Analysis to build Sharia Housing Property Business}

Strategy in the view of Islam is the application of business strategy discipline in accordance with sharia principles. The strategy in building the sharia housing business in Ngaliyan Residence is divided into 3 stages, namely:

\section{Pre-construction strategy}

1. Identification of mission or purpose

Besides having a mission to build housing with an Islamic and safe concept, the main mission of building the sharia housing business in Ngaliyan Residence is to build civilization. Civilization with a modern society and close to Islamic values, especially for children who are still in the age of learning and in the stage of searching for identity. This is what will become more value from Ngaliyan Residence.

2. Identification of the surrounding environment The environment at Ngaliyan Residence is an important matter for developers. Location is considered crucial to outdrawn potential consumers to to buy a house, because location determines how accessible a place for potential customers to visit such as sports, shopping, worship, etc. Ngaliyan Residence is located close to the airport, close to the center of Semarang, where there are business centers, government, places of worship, etc. Besides that, the developer also guarantees that the environment in Ngaliyan Residence is a safe environment and far from places where people do bad things like drunk or gambling, etc.

3. Identification of resources and capital

In the capital of the sharia residential property business, 'Ngaliyan Residence' uses the syirkah contract (cooperation agreement). Following the sunnah of the prophet Muhammad SAW, he had once ordered to make a ring, and at the time of the making up the ring, he had not paid in full, but after the ring is finished he paid it off. The illustration of the Prophet's sunnah above as a basis that buying and selling istishna is allowed. So the house ordered can be paid in partially for building costs. The customer can also use syirkah agreement regarding the capital for building this sharia housing business with investors.

4. Identification of business opportunities and threats

The opportunity of property business is excellent because of rapid growth rates. Undoubtedly, everyone wants to have assets like a house, either for settling or investment, so this business property will not be discharged in high demand and will continue to exist for the entire period. The credibility of Ngaliyan Residence in realizing sharia concept housing is a prior point offered in the property market. However, these advantages also have several shortcomings, including the complexity of administration and contract provisions that are required. It becomes a challenge for developers of Ngaliyan Residence in building their business. Finally, the strength, opportunities, barriers and challenges in composing a strategy of shariabased property business in Ngaliyan Residence is the reality that can't be left over.

\section{Strategies in the Construction stage}

In establishing a sharia-based business, Ngaliyan Residence always gives priority to the concepts of affection and pleasure from the seller or buyer and the blessing of Allah SWT. Thus, the procedure of building a business should be based on business ethics. One of it is discussing about providing a product. The product should be halal and thoyyib, necessary and valueable. It also has to have good 
potential to the economy, high added-value and stable. The examples of products that can satisfy the public include:

1. Building quality

2. Social facilities and public facilities, including; roads, water towers, public lighting, electricity networks, wall gates for landfills, and pavilions.

3. Culture

\section{Strategies in the Post-Construction stage}

Based on the analysis, the strategies in the post-construction stage are as follow:

1. Reduction strategy

Reduction strategy is a strategy designed to help 'Ngaliyan Rsidence' in preventing losses. This strategy is very necessary in building the sharia housing business because all prices or margins are determined at the beginning of the agreement. If the concept is applied to in rupiah value, the value of the developer or investor's profits will decrease as the value of inflation continues to increase. Then the sharia housing 'Ngaliyan Residence' applies a reduction strategy in payment concept. The concept of payment in sharia housing 'Ngaliyan Residence' is using gold, because the value of gold will always be more stable than the value of rupiah. So that every price or margin to be paid will be converted to the value of gold.

2. Competitive strategy

One thing that should be noted by the sellers in the competitive strategy is how the efforts undertaken by the developer in providing good service to consumers or costumers to satisfy them after buying the product or services offered so not influencing them to turn over to another company. Competition is one of the significant factors that can influence the company's goal. It can also be an effective way to encourage mind and performance. How the way of a company measures the level of customer satisfaction will determine the most appropriate service in this strategy.
3. Functional and marketing strategies Generally, a community is not only interested in the quality of the products but also take into account the quality of services offered by the seller. Service quality is totally needed in having a business since it functions to attract the customers.

Media promotion is a tool of promotion through both online and offline media. The media promotion used by "Ngaliyan Residence" is through both online media and offline marketing. For an online media, it uses website which specially advertises property while another media is through social media like instagram and youtube.

4. The market segmentation

Based on the analysis conducted by the developer, it is determined that the target market 'Ngaliyan Residence' is a new family that mostly has 2 children under 10 years old, and mostly works as a Manager and any other job that requires husband to leave his wife such as: shipping ,etc. The other target market of this business are; 1) urban middleclass people who are critical and want one totally to adopt Islamic lifestyles and, 2) people who are starting to discharge both conventional and sharia mortgages sold in the National Banking, but rather utilizing shariabased mortgage facilities on sharia housing but this mortgage is not product of financial institutions of any banking system but from the developer.

5. Evaluation Strategy

Initially the payment pattern in Ngaliyan Residence sharia housing had a maximum tenor of 1 year. In this concept we should customize the market needs. Then we change with a maximum tenor of 2 years, why do we set two years, based on surveys and analysis in many parties and many problems in installments or credit occurs during the third year. So that it can be reached by middle and upper class people with an average salary of 20 million / month. in addition to being able to repay to own a house they also can still 
fulfill the needs of his family. An evaluation strategy is needed to maintain the business over time so that continuity improvement is still stable.

The three stages of the strategy implemented at Ngaliyan residence have been able to complete customer satisfaction which ultimately can realize customer loyalty, where customer loyalty is characterized by: 1) repeat orders; 2) recommend to relatives, friends or other people to shop at the store (refers to others), 3) immunity to competitors, not be tempted by offers from other stores (immunity); and 4) harmonious relations.

\section{Sharia formulation on housing products}

Sharia housing business is the application of business rules that Islam teaches, sharia housing is based on sharia principles. Contracts that are used are also in accordance with sharia. The transaction activity of sharia housing business is halal as well and it prohibits usury or interest in its practice. The fulfillment of Ngaliyan Residence commitment in prioritizing buyer confidence and the sharia housing concept with all property ownership activities absolutely move to the buyer in accordance with sharia principles. As fiqh muamalah, one of the main pillars of property business stated is an object or goods can be owned by individuals, public interests or the state. So it is clarified as potential goods for business in which have been run by Ngaliyan Residence. Land and buildings in a geographical position are property of assets or immovable property. The abandonment gives the right consequences to use, or transfer the benefits to whoever the owner wants, including buying and selling land and buildings to own and occupy in the property business as explained by Ibn Manzhur in

From the above SWOT tabulations we can know that the strategy of building a residential property business in Ngaliyan Residence has several advantages including an easy process, leaving out usury, fines and confiscation, friendly service, and comfortable and safe housing products. However, the strategy to build a residential property business Ngaliyan Residence also has several obstacles including the lack of public knowledge of the concept of sharia housing and the absence of regulations that specifically regulate even though this product has been widely used in many cities in Indonesia.

\section{Conclusion}

Based on the previous description, it can be concluded that the result of the analysis of Ngaliyan Residence Syariah Housing Property business answers 9 reference points of BMC (Business Model Canvas) analysis which Includes Value Proportion, Customer Segments, Channels, Customer Relationships, Key Resources, Key Activities, Key Partnerships, and Cost Structure. Ngaliyan Residence offers a Value Proposition in the form of Sharia Housing in which the housing ownership is provided by property developers based on sharia principles by implementing principles in accordance with the Qur'an and Sunnah by the aim of creating housing with Islamic civilization. This value proposition is a distinct point for another residence. For other 8 points in the BMC analysis are applied in the process of buying and selling process such as these sharia developers do not use the services of banking financial institutions. Syariah Ngaliyan Residence Housing also offers a different payment concept from another housing that is with gold since the price of the house at the beginning contract is also converted to the value of gold.

\section{References}

Amin, H., Abdul-Rahman, A. R., \& AbdulRazak, D. (2013). An integrative approach for understanding Islamic home financing adoption in Malaysia. International Journal of Bank Marketing. https://doi.org/10.1108/IJBM-02-2013-0008 Arifin, J. (2009). Etika Bisnis Islam. Semarang: Walisongo Press. 
BPS. (2010). Badan Pusat Statistik. Retrieved April 9, 2019, from https://sp2010.bps.go.id/index.php/site/tabel ?tid $=321 \&$ wid $=0$

Cordell, A., Thompson, I., Cordell, A., \& Thompson, I. (2019). Ansoff Matrix. In The Procurement Models Handbook. https://doi.org/10.4324/9781351239509-14

Faisal, Badroen, dkk. (2006). Etika Bisnis dalam Islam. Jakarta: Kencana.

Firmansyah, E. A., \& Gunardi, A. (2018). A New Paradigm in Islamic Housing: NonBank Islamic Mortgage. Al-Iqtishad: Jurnal Ilmu Ekonomi Syariah, 10(2), 313-324. https://doi.org/10.15408/aiq.v10i2.7274

Hamid, A., \& Masood, O. (2011). Selection criteria for Islamic home financing: a case study of Pakistan. Qualitative Research in Financial Markets, 3(2), 117-130. https://doi.org/10.1108/17554171111155357 Hery S.E., M. S. (2002). Mahir Mengelola Bisnis dalam 30 hari. Yogyakarta: Gava Media.

Kountur, R. (2009). Metode penelitian untuk penulisan skripsi dan tesis. In PPM Manajemen.

https://doi.org/10.1002/ajh.23895

Lubis, I. (1994). Ekonomi Islam: Suatu Pengantar (Cet. 1). Jakarta: Kalam Mulia.

Mintzberg, H. (1987). The Strategy Concept I: Five Ps For Strategy. California Management Review. https://doi.org/10.2307/41165263

Muhammad Fauroni, R. L. (2002). Visi AlQur'an Tentang Etika dan Bisnis. Jakarta: Salemba Diniyah.

Mulyana, D. (2001). Metodologi Penelitian Kualitatif: Paradigma Baru Ilmu Komunikasi dan Ilmu Sosial Lainnya. In Bandung: PT remaja Rosdakarya.
Oktavianingrum, Y. (2016). Analisis Preferensi Nasabah Terhadap Pembiayaan Kredit Kepemilikan Rumah (KPR) Antara Bank Umum Syariah Dan Bank Umum Konvensional (Studi Kasus di Kota Malang). Jurnal Ilmiah.

Prof. Dr. H. Muhammad Djakfar, S.H., M. A. (2012). Etika Bisnis Menangkap Spirit Ajaran Langit dan Pesan Moral Ajaran Bumi (first Edit). Jakarta: Penebar Plus.

Solihin, I. (2012). Manajemen Strategik. Jakarta: Erlangga.

Umar Shihab. (2005). Kontekstualitas Al Qur'an: Kajian tematik Atas Ayat-Ayat Hukum dalam AL-Qur'an (Hasan M. Noer, Ed.). Jakarta: Penamadani.

Wulandari, P., Putri, N. I. S., Kassim, S., \& Sulung, L. A. (2016). Contract agreement model for murabahah financing in Indonesia Islamic banking. International Journal of Islamic and Middle Eastern Finance and Management.

https://doi.org/10.1108/IMEFM-01-20150001

Yahya, A. (2016). Jurnal ilmiah. Jurnal Ilmiah, $10(2)$,

https://doi.org/10.1017/CBO9781107415324 .004

Azzam, H.T., (2002). There's considerable rationale to invest in Arab stock markets, Middle East Executive Reports 25, 6-10.

Erdem, C., Arslan, C. K., \& Sema Erdem, M. (2005). Effects of macroeconomic variables on Istanbul stock exchange indexes. Applied Financial Economics, 15(14), 987-994. 